\title{
Tree Growth and Resilience to Extreme Drought Across an Urban Land-use Gradient
}

\author{
Robert T. Fahey, Margaret B. Bialecki, and David R. Carter
}

\begin{abstract}
Understanding the response of urban forests to extreme climatic events, such as drought, will be essential to predicting impacts of climate change on the urban tree canopy and related ecosystem services. This study evaluated variation in tree growth and drought resistance (growth during drought) and resilience (growth in period following drought) across four land-use categories (built, transportation, park, and semi-natural forest) and four species (Acer saccharum, Gymnocladus dioicus, Liriodendron tulipifera, and Pinus strobus) at The Morton Arboretum in suburban Lisle, Illinois, U.S. Tree growth and resistance to drought both varied as an interaction between land-use and species $\left(\mathrm{F}_{15,100}=5.25, \mathrm{p}<0.001 ; \mathrm{F}_{15,100}=2.42, \mathrm{p}=0.005\right)$. Resilience of tree growth to extreme drought was generally high and did not vary across species and land-uses. In this study, individual tree species responses to drought varied across land-uses, illustrating the difficulty of predicting the reaction of urban forests to projected increases in the frequency of extreme climatic events. Tree growth response to drought varied even across the relatively narrow range of growing conditions studied here. Investigation of a broader range of sites, encompassing the full urban forest continuum, would likely demonstrate even greater variation in tree response to extreme climatic events.

Key Words. Climate Change; Drought; Growth; Gymnocladus dioicus; Land-use; Liriodendron tulipifera; Pinus strobus; Resilience; Urban Forest.
\end{abstract}

Trees in metropolitan regions grow in sites that span a wide range of land-uses and specific environmental conditions. What is commonly referred to as the urban forest (street trees, landscape plantings, urban parks), is only a small component of a larger continuum that also includes natural areas, agricultural remnants, and interstitial stands. The wide variation in growing conditions across this continuum likely has a strong impact on the growth, resiliency, and mortality of the trees that make up the urban forest (Iakovoglou et al. 2001; Nowak et al. 2004). For example, the volume, structure, and composition of soil in the rooting zone can have a considerable impact on tree growth (Whitlow and Bassuk 1987; Lindsey and Bassuk 1992). Variables that are linked to specific land-uses, such as pollution associated with transportation corridors, can also affect tree growth (Benoit et al. 1982; Muir and McCune 1988). Environmental factors that occur at a larger scale can also be important; for instance, the urban heat island effect can influence both tree growth and resilience to environmental perturbations, such as drought (Cregg and Dix 2001).

Urban forests will play a very important role in climate change mitigation and adaptation; however, the effects that global climate change will have on the urban forest are difficult to predict and may be affected by changing urban land-uses (McPherson et al. 1997). Carbon sequestration associated with tree growth in urban areas could have an important mitigating effect on climate change (Nowak and Crane 2002). Average annual temperatures are projected to increase with global climate change, but specific changes at the regional scale, especially changes in precipitation amounts and timing, are difficult to predict accurately. However, the frequency of extreme climatic events, such as drought, floods, and heat waves, is projected to increase, and these events may be especially influential on urban ecosystems (Meehl et al. 2007).
Urban forests may have the capacity to help mitigate some of these events, through such functions as their influence on water movement and the shading of buildings (McPherson et al. 1997). However, the capacity of urban forests to mitigate deleterious climatic changes will depend on maintaining healthy canopy cover. In the long-term, the response of the species that make up the urban forest to general climate warming will be very important to maintaining a healthy forest (Woodall et al. 2010). In the near-term, though, the response of trees in the urban landscape to extreme climatic events will likely be more important to maintaining canopy cover. In order to understand how the urban forest will respond to future climatic changes and land-use conversion, planners need to know how tree growth and resilience to extreme climatic conditions vary across the urban landscape and among species.

This study addresses three research questions regarding the response of trees to extreme climatic events across a gradient in urban land-use: 1) How does tree growth differ across urban land-use categories and species? 2) How does sensitivity of tree growth to general climatic conditions vary with land-use and species? 3) Does resistance and resilience of urban trees to extreme drought vary among species and land-use categories?

\section{METHODS}

\section{Study Area and Sampling Methods}

The study was conducted on the grounds of The Morton Arboretum (hereafter "Morton") in Lisle, Illinois, U.S., which is in the western part of the Chicago metropolitan region. Mean temperatures in the area range between $-5.3^{\circ} \mathrm{C}$ in January and $22.3^{\circ} \mathrm{C}$ in July, and mean annual precipitation averages $98.5 \mathrm{~cm}$ 
(Angel 2011). Within the Morton landscape, a range of urban land-use categories were sampled: built (near buildings, parking lots), transportation (along major roadways - Interstate-88, IL-53), park (tree collections with grass or other landscaped understory conditions), and forest (semi-natural forest conditions). To assess variation in species responses across these land-use categories, four tree species that are commonly planted in the urban forest were sampled: Kentucky coffeetree (Gymnocladus dioicus), eastern white pine (Pinus strobus), sugar maple (Acer saccharum), and tulip-tree (Liriodendron tulipifera). These species vary in their tolerance to drought conditions, with white pine and coffeetree both having considerable drought tolerance and sugar maple and tulip-tree both exhibiting susceptibility to low moisture conditions (Gilman and Watson 1993; Orwig and Abrams 1997; Caspersen and Kobe 2001). However, tolerance of low-moisture conditions is likely to be highly conditional on the characteristics of the individual plant (e.g., age, size, root-shoot ratio) and is likely to be site-dependent as well, making specific a priori predictions about drought impacts on species difficult.

To examine tree growth response to historical climate, increment cores were collected from at least 25 trees in each land-use category and from at least 25 trees of each species. However, not all cores were readable, and so sample sizes varied among both land-uses and species (Table 1). Cores were collected at $1.37 \mathrm{~m}$ and attempted to capture at least 20 years of growth increments. Increment cores were mounted on grooved wood blocks and sanded using progressively finer sandpaper to help distinguish rings. Annual growth increments were measured with a Velmex stage micrometer using Measure J2X software (Voortech 2005).

\section{Data Analysis}

Yearly growth for each tree was calculated by converting ring width to basal area increment (BAI) by back calculating basal area based on current diameter and annual ring widths. Total growth increment over the past 15 years (1997-2011) was calculated for each tree. To account for the effect of tree size and age on growth in comparing across land-use categories, BAI for each tree was adjusted for starting diameter and tree age. A multiple regression equation explaining BAI as a function of age and starting diameter (in 1997) was fit to the data and an expected BAI value was calculated for each tree based on the resulting equation:

[1] $\quad$ Expected $\mathrm{BAI}_{1997-2011}=225.10+0.63 \cdot(\mathrm{BA})+$ $[-3.1619 \bullet($ Age $)]+[-0.0045 \bullet($ Age $\bullet B A)]$

Actual total BAI for each tree over the 15-year study period was then scaled by this expected value to produce a scaled BAI value using the following equation:

[2] $\quad$ Scaled BAI $=$ Total BAI $\bullet[($ Total BAI $\bullet$ Expected BAI $)$ $\left./(\text { Expected BAI })^{2}\right]$
Variation in growth was also assessed by calculating the coefficient of variation $(\mathrm{CV}$; standard deviation/mean) of BAI for each tree over the same 15-year period. Both scaled BAI and CV of BAI were compared among land-use categories (Question 1) using analysis of variance (ANOVA). All ANOVA analyses were conducted using PROC GLM in SAS v.9.2 (SAS-Institute-Inc. 2005) and Tukey-Kramer adjustments were applied to means comparisons.

In order to assess differences among land-use categories in sensitivity of tree growth to environmental variation (Question 2), the correlation of BAI with annual and growing season (May-October) precipitation was determined for each tree. For the 15-year period of interest, annual and growing season precipitation were determined based on climate records from the Wheaton climate monitoring station (Angel 2011). Correlation of BAI with precipitation was then calculated for each tree and compared among land-use categories and species using ANOVA.

To evaluate variability in growth in relation to extreme drought (Question 3), researchers investigated tree growth responses to a drought that occurred in 2005 (considered one of the three most intense droughts in the historical record in Illinois; Kunkel et al. 2006). Statewide, an average of only $50.01 \mathrm{~cm}$ of precipitation fell during the period of March-October 2005 (compared with statewide normal of $74.22 \mathrm{~cm}$; Kunkel et al. 2006). Drought resistance can be defined as the ability of a tree to maintain growth under drought conditions. A drought resistance index can be calculated by comparing growth in the drought year relative to average growth over the previous five-year period: BAI2005/mean BAI2000-04 (D'Amato et al. 2011). Resilience to drought is the ability of a tree to return growth to pre-drought levels in the period following the drought. A drought resilience index was defined as the average growth in the five years following the drought relative to pre-drought growth: resilience index = mean BAI2006-10/ mean BAI2000-04 (D'Amato et al. 2011). For these indices, values $<1$ indicate a negative growth response in the year of the drought (resistance) or the five-year period following the drought (resilience) relative to pre-drought growth rates. Drought resistance and resilience indices were compared among land-use categories and species using ANOVA.

\section{RESULTS}

Growth differed strongly among land-use categories even after accounting for differences in age and diameter $\left(\mathrm{F}_{3,112}=12.97, \mathrm{p}<\right.$ 0.001; Figure 1a). The highest growth rates were seen in the park land-use category, with both forest and transportation having lower total growth (Figure 1a). There was also a significant interaction between land-use and species in growth $\left(\mathrm{F}_{15,100}=6.49, \mathrm{p}<\right.$ 0.001 ), as tulip-tree and white pine, both shade-intolerant earlysuccessional species, had greater growth rates in the park land-use than the other species (Figure 2a). Variation in growth was generally relatively low (average $\mathrm{CV}=0.49$ ) and did not differ significantly among land-use categories $\left(\mathrm{F}_{3,112}=1.94, \mathrm{p}=0.13\right.$; Figure

Table 1. Count of readable increment cores by land-use category and species.

\begin{tabular}{|c|c|c|c|c|c|}
\hline Land-use category & Sugar maple & Kentucky coffeetree & Tulip-tree & White pine & Total \\
\hline Built & 9 & 7 & 4 & 11 & 31 \\
\hline Forest & 8 & 3 & 8 & 8 & 27 \\
\hline Park & 8 & 6 & 10 & 9 & 33 \\
\hline Total & 29 & 21 & 29 & 37 & 116 \\
\hline
\end{tabular}


1b), but the interaction between species and land-use was only marginally non-significant $\left(F_{15,100}=1.73, p=0.056\right.$, Figure $\left.2 b\right)$.

The correlation between precipitation and total basal area increment (across all trees) was somewhat strong (annual $-\mathrm{r}=$ 0.42 , growing season $-r=0.50$; Figure 3 ). There was a significant difference among land-use categories in the correlation between growth and total annual precipitation (Figure 4), but not growing season precipitation. However, the correlation between growth of individual trees and precipitation was not consistently high. The highest correlation in any core series was only $r=0.54$, and the average correlations of precipitation and individual tree growth were low (annual $-r=0.18$, growing season $-r=0.19$ ).

Overall, growth in 2005 was only $68 \%$ of that seen in the five-year period prior to the drought and $86 \%$ of trees showed a reduction in growth in the year of the drought. Resistance to drought did not differ among land-uses $\left(\mathrm{F}_{3,113}=1.64, \mathrm{p}=0.184\right.$; Figure $5 b)$, but did differ among species $\left(\mathrm{F}_{3,113}=5.30, \mathrm{p}=0.002\right.$; Figure 5a). Kentucky coffeetree was more resistant to drought than the other species, and actually averaged higher growth in 2005 than in the pre-drought period, while tulip-tree appeared to be the least resistant to drought impacts (Figure 5a). There was also a significant interaction between species and land-use in

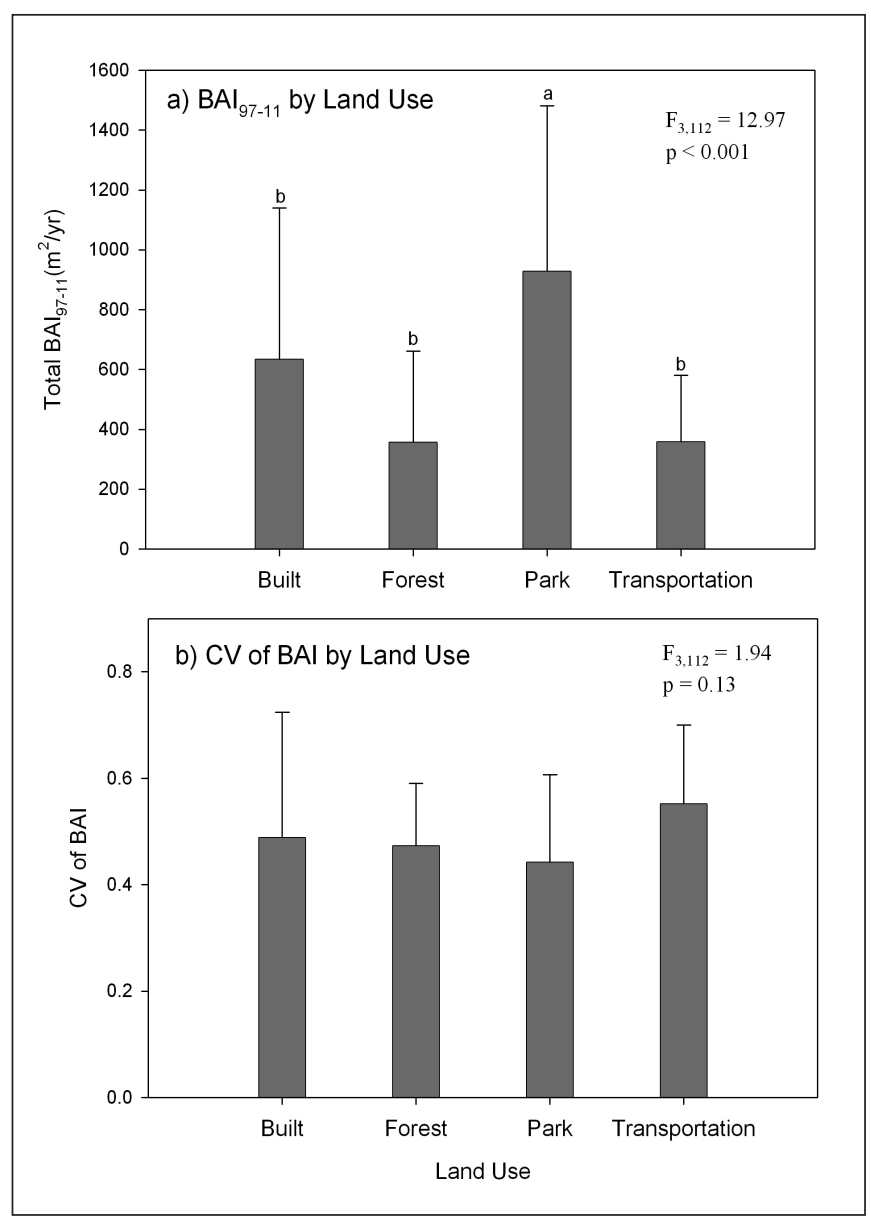

Figure 1. Total basal area increment (a) and coefficient of variation of basal area increment (b) over the period of 1997-2011 by land-use category with results of analysis of variance comparing among categories. Means with the same letter did not differ based on least-squares means comparisons with Tukey-Kramer adjustment; bars indicate standard deviation. drought resistance. Kentucky coffeetree was especially resistant in park locations, while white pine appeared to be more resistant in built areas (Figure 6a). Trees in all locations appeared to be highly resilient to drought effects, as growth in the five years post-drought was equal to pre-drought growth overall (average resilience index was 1.00). A relatively large percentage of trees $(47 \%)$ actually showed higher growth in the post-drought period. There was no difference in drought resilience among either landuse categories $\left(\mathrm{F}_{3,113}=1.67, \mathrm{p}=0.179\right.$; Figure $\left.5 \mathrm{~b}\right)$ or species $\left(\mathrm{F}_{3,113}=0.81, \mathrm{p}=0.489 ;\right.$ Figure $\left.5 \mathrm{a}\right)$, as most species appeared to be relatively resilient across all land-use categories (Figure 6b).

\section{DISCUSSION}

Urban tree growth and resistance to drought both varied as an interaction among species and land-uses, illustrating the complexity associated with forecasting the response of the urban forest to climate change. Iakovoglou et al. (2002) did not observe an interaction between tree species and land-use in urban tree growth. Therefore, the finding in this study that not all species responded similarly across land-use categories is intriguing, and suggests an interaction between physiology and site conditions.

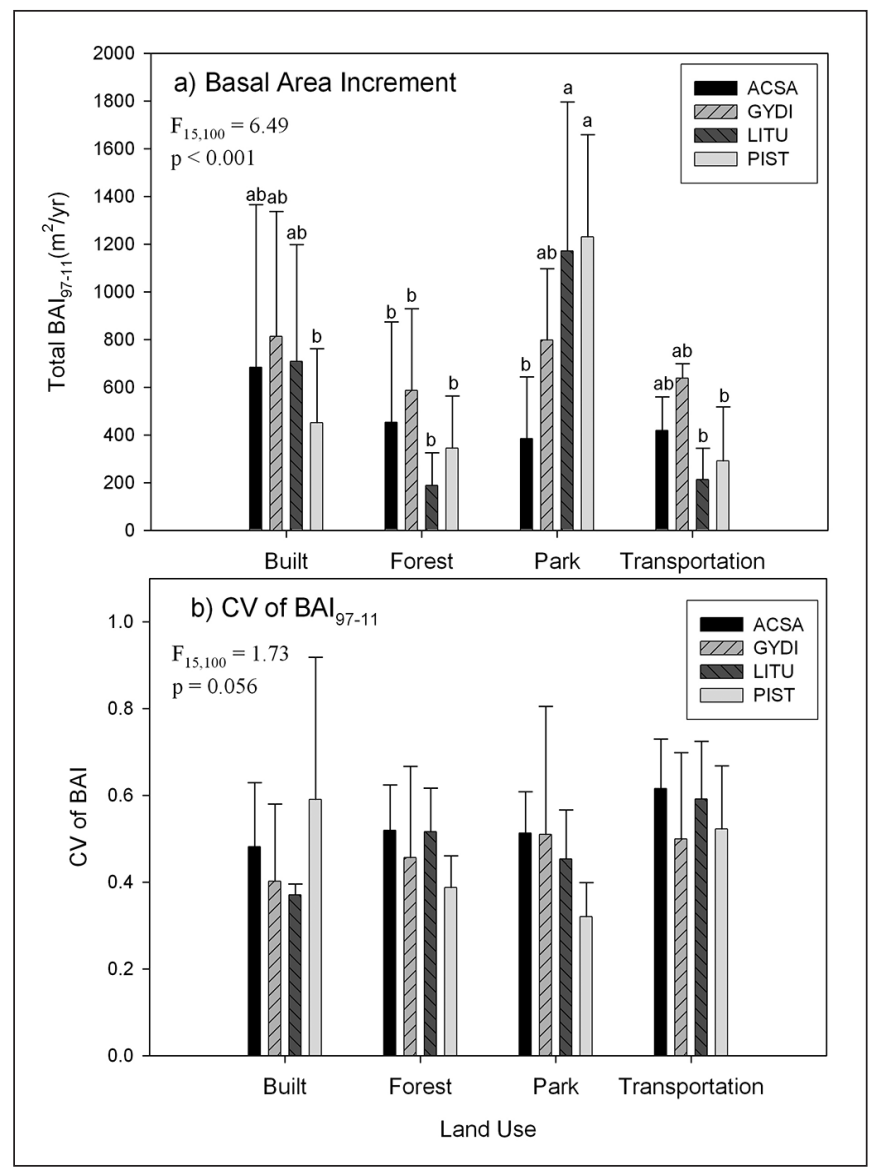

Figure 2. Total basal area increment (a) and coefficient of variation of basal area increment (b) over the period of 1997-2011 by land-use and species with results of analysis of variance comparing category and species means. Means with same letter did not differ based on least-squares means comparisons with TukeyKramer adjustment; bars indicate standard deviation. 
Understanding such interactive relationships in climate response between tree species and land-uses will be critical to projecting the impacts of climate change and land-use conversion on the urban forest, and to optimizing future tree planting campaigns.

Variation in tree species growth and drought response among land-uses is likely related to general characteristics of the landuse category (e.g., physical impediments in built areas, pollutants in transportation corridors, and competition in forests); specific characteristics of planting sites, such as water holding capacity of the soil (Clark and Kjelgren 1990); and physiological differences among species, which can lead to individualistic responses of tree species to drought (Orwig and Abrams 1997). Some of the species variation among land-uses could be easily predicted based on characteristics of the land-use or individual species. For example, the difference in growth of the relatively shade-intolerant tuliptree and white pine between park and forest settings (basically with and without competition) was not unexpected. In addition, the tree that was least affected by the intense 2005 drought event was Kentucky coffeetree, which is known to be a highly drought-

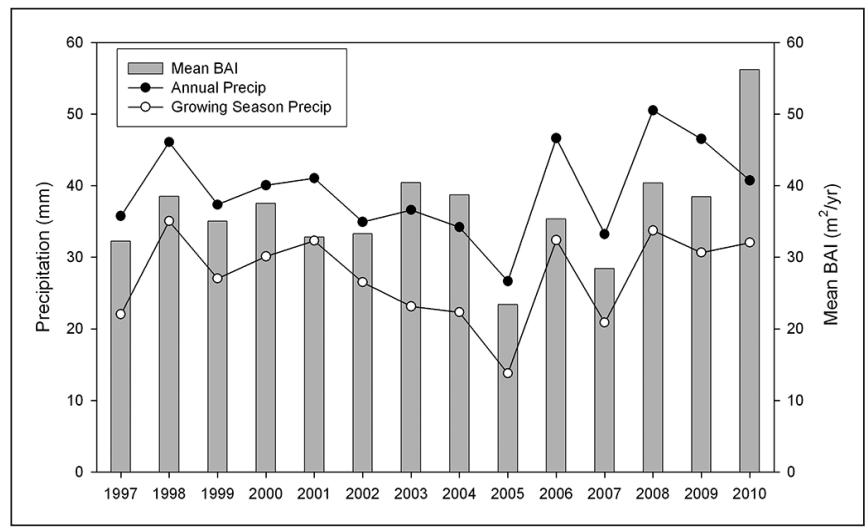

Figure 3. Annual and growing season precipitation for the 19972010 period and mean annual basal area increment for all trees during the same period.

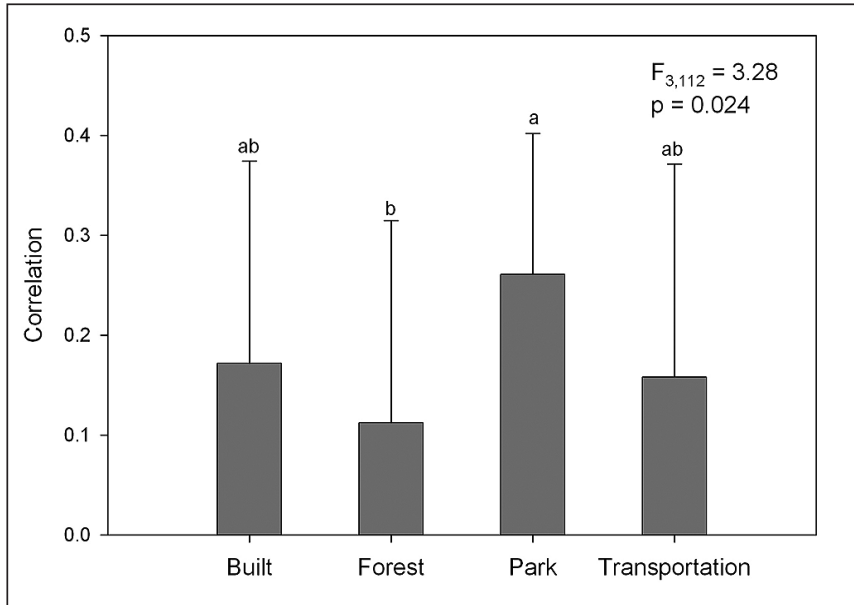

Figure 4. Mean correlation between basal area increment and precipitation for all trees in each land-use category with results of analysis of variance comparing among categories. Means with same letter did not differ based on least-squares means comparisons with Tukey-Kramer adjustment; bars indicate standard deviation. tolerant species (Gilman and Watson 1993). Sugar maple and tuliptree had the least overall resistance to the impacts of the drought, and both have previously been shown to have their growth more negatively affected by drought than co-occurring species (Orwig and Abrams 1997; Horsley et al. 2002). However, other patterns were less straightforward, for example, white pine and Kentucky coffeetree did not differ strongly in their resistance to the drought overall, but their response was very different in relation to landuse. Such interactions are likely associated with differences among species in drought tolerance strategies and their interaction with growing conditions and competition intensity in different landuse types (Orwig and Abrams 1997; Poorter and Markesteijn 2008). However, differences in growth responses could also be related to variation within land-use categories in growing conditions (e.g., rooting zone volume, soil structure) or other environmental factors (e.g., high salt levels in transportation corridors), which were not quantified at the specific growing sites in this study.

In this study, urban tree growth was generally quite resistant and resilient to the effects of extreme drought across a range of
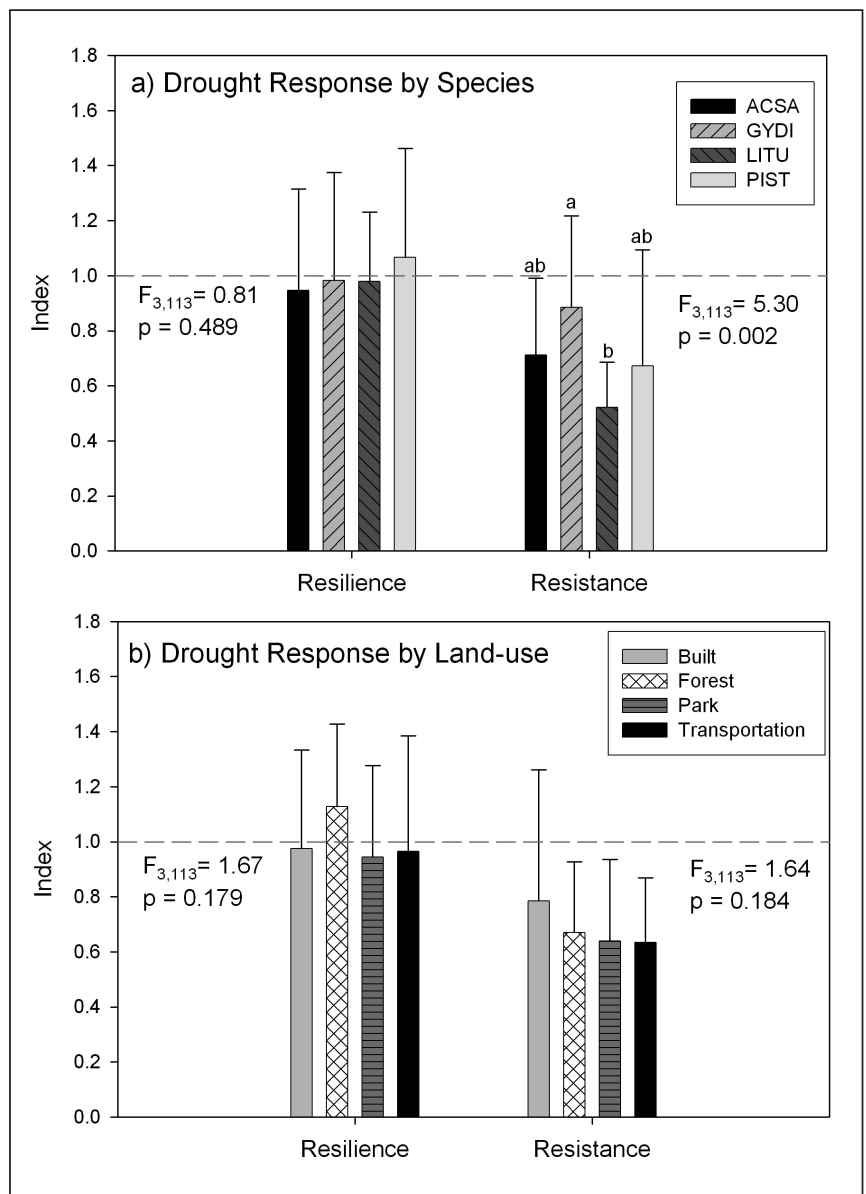

Figure 5. Indices of resistance and resilience to 2005 drought by a) species and b) land-use, with analysis of variance results for comparisons among species and land-use categories. Means with same letter did not differ based on least-squares means comparisons with Tukey-Kramer adjustment; bars indicate standard deviation. 


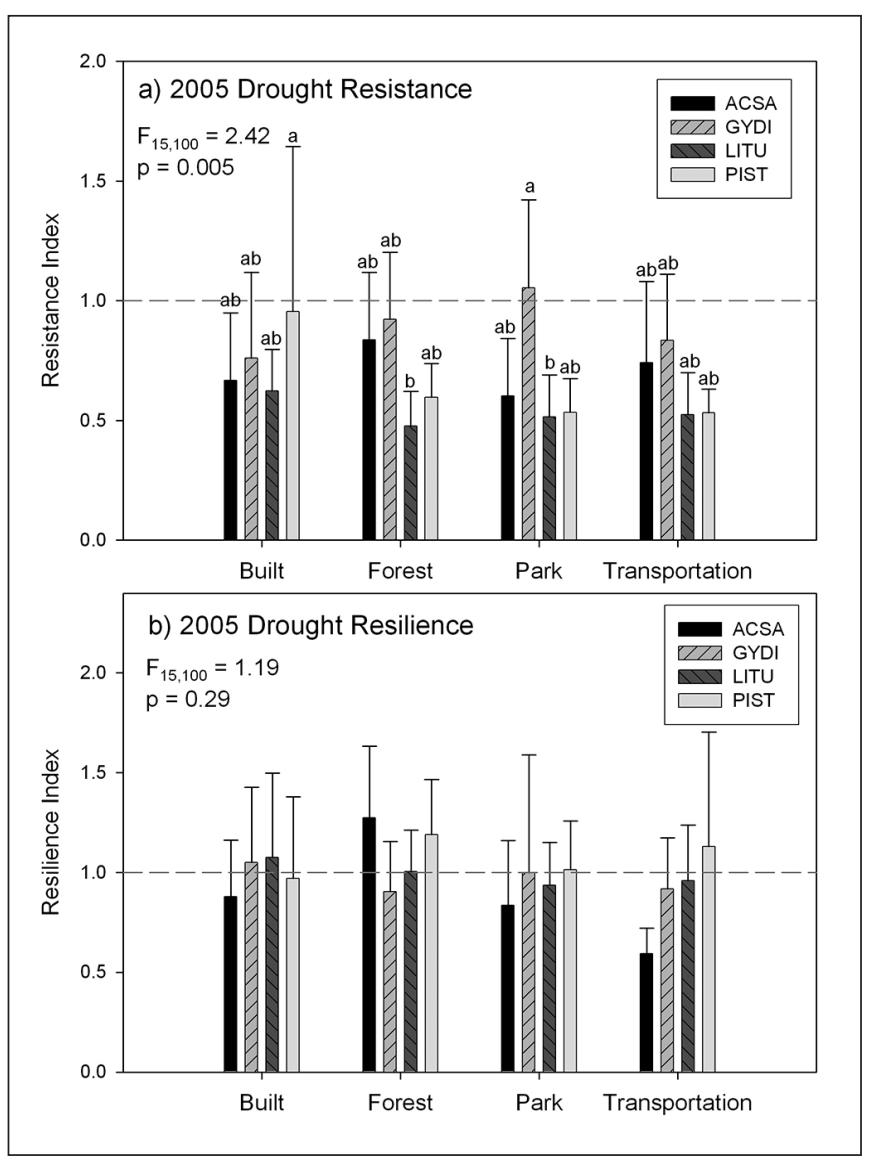

Figure 6. Indices of a) resistance and b) resilience to 2005 drought by species and land-use, with analysis of variance results for interactions among species and land-use categories. Means with same letter did not differ based on least-squares means comparisons with Tukey-Kramer adjustment; bars indicate standard deviation.

species and land-use types. Growth was reduced in the year of the drought, but the trees rapidly returned to pre-drought growth despite the very low moisture and unusually high temperatures associated with the 2005 drought, conditions that have been termed "global-change-type" drought and have been shown to result in tree mortality in the southwestern United States (Breshears et al. 2005; Breshears et al. 2008). The relatively short duration of the 2005 drought, which was restricted to a single growing season, could have had some bearing on this response, as longer-term droughts may be more likely to result in high levels of tree mortality (Mueller et al. 2005). Long-term drought can lead to protracted water stress, which may result in carbon starvation (prolonged negative carbon balance) or hydraulic failure in roots and stems (McDowell et al. 2008). The period following the 2005 drought was characterized by high precipitation levels (Figure 3), which also likely contributed to the apparent resilience of the trees in this system.

Resistance to the drought was also relatively high across all of the land-use categories, and two of the species (white pine and tulip-tree) showed somewhat higher resistance in the built areas of the landscape. Previous research has shown that excess soil water is often more of a problem in urban tree plantings than water deficits (Berrang et al. 1985), and built locations may not be especially susceptible to drought if well maintained (Whitlow and Bassuk
1987). The high water-holding capacity and low belowground competition often found in urban plantings could explain the finding that trees in the built landscape were slightly more resistant to drought impacts. However, another potential explanation for the apparent drought resistance of trees in this study system, especially in built areas, is that they may have received residual water from irrigation of nearby landscape plantings during the drought period (although direct watering is not known to have taken place).

The variance in growing conditions across the Morton landuse gradient assessed in this study is much narrower than what is likely to be seen across an entire metropolitan region. Growing conditions in built areas at Morton likely offer much less stress than those in the urban core or in developments with highly compacted soils (Whitlow and Bassuk 1987). For example, the urban heat island effect could exacerbate the effects of drought, but the heavy dominance of tree canopy cover at Morton probably mitigates this effect to some degree, increasing the resilience of trees in this landscape to drought (McPherson et al. 1997; Cregg and Dix 2001). Therefore, the finding that there were some differences in growth and response to drought within the relatively narrow gradient represented by the Morton site, suggests that investigation of a full continuum of land-uses across an urbanized landscape would likely show even more variation.

Previous studies of urban tree growth have focused on characteristics of specific planting sites (Pan and Bassuk 1985; Whitlow and Bassuk 1987; Kjelgren and Clark 1992) and urban-rural gradients (Iakovoglou et al. 2001; Iakovoglou et al. 2002). The first approach is superior in some respects to the land-use category analysis presented here, because it offers a more mechanistic understanding of the factors that impact growth variability. However, with such a reductive approach it would be difficult to assess how variation in urban tree growth will respond at a landscape- or regional-scale to stressors such as climate change. Studies that assess urban to rural gradients have this capacity but have often overlooked much of the variation that occurs within the urban portion of the gradient (Iakovoglou et al. 2001; Iakovoglou et al. 2002). The approach outlined here, applied at a regional-scale and expanded to the full continuum of urban land-uses, would be very useful in assessing the potential impacts of climate change and urban land-use change on urban forest health and carbon sequestration. However, some degree of characterization of specific growing conditions and their variation within land-use classes would be useful in avoiding issues associated with land-use categorization (Cadenasso et al. 2007) and still allow for application at a regional-scale.

Acknowledgments. Funding for this project was provided by The Morton Arboretum, and data collection assistance was provided by volunteers in The Morton Arboretum Forest Ecology Lab. For comments on the manuscript we thank two anonymous reviewers.

\section{LITERATURE CITED}

Angel, J.R. 2011. Illinois Climate Normals (updated to 1981-2010). Illinois State Water Survey, Champaign, Illinois, U.S. <www.isws. illinois.edu/atmos/statecli/newnormals/newnormals.htm>

Benoit, L., J. Skelly, L. Moore, and L. Dochinger. 1982. Radial growth reductions of Pinus strobus L. correlated with foliar ozone sensitivity as an indicator of ozone-induced losses in eastern forests. Canadian Journal of Forest Research 12:673-678. 
Berrang, P., D. Karnosky, and B. Stanton. 1985. Environmental factors affecting tree health in New York City. Journal of Arboriculture 11:185-189.

Breshears, D.D., N.S. Cobb, P.M. Rich, K.P. Price, C.D. Allen, R.G. Balice, W.H. Romme, J.H. Kastens, M.L. Floyd, and J. Belnap. 2005. Regional vegetation die-off in response to global-change-type drought. Proceedings of the National Academy of Sciences of the United States of America 102:15144.

Breshears, D.D., O.B. Myers, C.W. Meyer, F.J. Barnes, C.B. Zou, C.D. Allen, N.G. McDowell, and W.T. Pockman. 2008. Tree die-off in response to global change-type drought: Mortality insights from a decade of plant water potential measurements. Frontiers in Ecology and the Environment 7:185-189.

Cadenasso, M.L., S.T.A. Pickett, and K. Schwarz. 2007. Spatial heterogeneity in urban ecosystems: Reconceptualizing land cover and a framework for classification. Frontiers in Ecology and the Environment 5:80-88.

Caspersen, J.P., and R.K. Kobe. 2001. Interspecific variation in sapling mortality in relation to growth and soil moisture. Oikos 92:160-168.

Clark, J., and R. Kjelgren. 1990. Water as a limiting factor in the development of urban trees. Journal of Arboriculture 16:203-208.

Cregg, B.M., and M.E. Dix. 2001. Tree moisture stress and insect damage in urban areas in relation to heat island effects. Journal of Arboriculture 27:8-17.

D’Amato, A.W., J. Bradford, S. Fraver, and B.J. Palik. 2011. Looking back to inform the future: The effects of thinning and stand complexity on drought tolerance within Pinus resinosa systems. Eighth North American Forest Ecology Workshop: Forest Ecology in a Managed Landscape. Roanoke, Virginia, U.S.

Gilman, E.F., and D.G. Watson. 1993. Gymnocladus dioicus - Kentucky Coffeetree. Fact Sheet ST-287. Environmental Horticulture Department, Florida Cooperative Extension Service, Institute of Food and Agricultural Sciences, University of Florida.

Horsley, S.B., R.P. Long, S.W. Bailey, R.A. Hallett, and P.M. Wargo. 2002. Health of eastern North American sugar maple forests and factors affecting decline. Northern Journal of Applied Forestry 19:34-44.

Iakovoglou, V., J. Thompson, and L. Burras. 2002. Characteristics of trees according to community population level and by land use in the US Midwest. Journal of Arboriculture 28:59-69.

Iakovoglou, V., J. Thompson, L. Burras, and R. Kipper. 2001. Factors related to tree growth across urban-rural gradients in the Midwest, USA. Urban Ecosystems 5:71-85.

Kjelgren, R.K., and J.R. Clark. 1992. Microclimates and tree growth in three urban spaces. Journal of Environmental Horticulture 10:139-145.

Kunkel, K.E., J.R. Angel, S.A. Changnon, R. Claybrooke, S.D. Hilberg, H.V. Knapp, R.S. Larson, M. Palecki, R.W. Scott, and D. Winstanley. 2006. The 2005 Illinois Drought. Illinois State Water Survey, Champaign, IL.

Lindsey, P., and N. Bassuk. 1992. Redesigning the Urban Forest from the ground below. A new approach to specifying adequate soil volumes for street trees. Arboricultural Journal 16:25-39.

McDowell, N., W.T. Pockman, C.D. Allen, D.D. Breshears, N. Cobb, T. Kolb, J. Plaut, J. Sperry, A. West, and D.G. Williams. 2008. Mechanisms of plant survival and mortality during drought: Why do some plants survive while others succumb to drought? New Phytologist 178:719-739.
McPherson, E.G., D. Nowak, G. Heisler, S. Grimmond, C. Souch, R. Grant, and R. Rowntree. 1997. Quantifying urban forest structure, function, and value: The Chicago Urban Forest Climate Project. Urban Ecosystems 1:49-61.

Meehl, G.A., T.F. Stocker, W.D. Collins, P. Friedlingstein, A.T. Gaye, J. Gregory, A. Kitoh, R. Knutti, J. Murphy, and A. Noda. 2007. Global climate projections. Climate Change:747-845.

Mueller, R.C., C.M. Scudder, M.E. Porter, R. Talbot Trotter III, C.A. Gehring, and T.G. Whitham. 2005. Differential tree mortality in response to severe drought: Evidence for long-term vegetation shifts. Journal of Ecology 93:1085-1093.

Muir, P., and B. McCune. 1988. Lichens, tree growth, and foliar symptoms of air pollution: Are the stories consistent? Journal of Environmental Quality 17:361-370.

Nowak, D.J., and D.E. Crane. 2002. Carbon storage and sequestration by urban trees in the USA. Environmental Pollution 116:381-389.

Nowak, D.J., M. Kuroda, and D.E. Crane. 2004. Tree mortality rates and tree population projections in Baltimore, Maryland, USA. Urban Forestry \& Urban Greening 2:139-147.

Orwig, D.A., and M.D. Abrams. 1997. Variation in radial growth responses to drought among species, site, and canopy strata. TreesStructure and Function 11:474-484

Pan, E., and N. Bassuk. 1985. Effects of Soil Type and Compaction on the Growth of Ailanthus altissima seedlings. Journal of Environmental Horticulture 3:158-162.

Poorter, L., and L. Markesteijn. 2008. Seedling traits determine drought tolerance of tropical tree species. Biotropica 40:321-331.

SAS-Institute-Inc. 2005. SAS v. 9.2. SAS Institute Inc., Durham, North Carolina, U.S.

Voortech. 2005. Measure J2X, Holderness, New Hampshire, U.S.

Whitlow, T.H., and N.L. Bassuk. 1987. Trees in Difficult Sites. Journal of Arboriculture 13:10-17

Woodall, C., D. Nowak, G. Liknes, and J. Westfall. 2010. Assessing the potential for urban trees to facilitate forest tree migration in the eastern United States. Forest Ecology and Management 259:1447-1454.

Robert T. Fahey (corresponding author)

The Morton Arboretum

4100 Illinois Route 53

Lisle, Illinois 60532, U.S.

rfahey@mortonarb.org

Margaret B. Bialecki

The Morton Arboretum

4100 Illinois Route 53

Lisle, Illinois 60532, U.S.

David R. Carter

The Morton Arboretum

4100 Illinois Route 53

Lisle, Illinois 60532, U.S. 
Zusammenfassung. Ein Verständnis der Reaktion urbaner Wälder auf extreme Klimaereignisse, so wie Trockenheit, wird wichtig, um Vorhersagen zum Einfluss klimatischer Veränderung auf die urbane Kronenbedeckung und damit verbundene Ökosystemleistung zu machen. Diese Studie bewertet Variationen in Wachstum und Trockenheitsresistenz (Wachstum während der Trockenheit) und Widerstandsfähigkeit (Wachstum in der Periode nach der Trockenheit) in vier Landnutzungskategorien (bebaut, Verkehr, Park und seminatürliche Wälder) und vier Baumarten (Acer saccharum, Gymnocladus dioicus, Liriodendron tulipifera, und Pinus strobus) im Morton Arboretum in der Umgebung von Chicago, Illinois, U.S. Baumwachstum und Widerstandsfähigkeit gegen Trockenheit variierte als eine Interaktion zwischen Landnutzung und Baumart $(\mathrm{F} 15,100=5.25, \mathrm{p}<0.001 ; \mathrm{F} 15,100=2.42, \mathrm{p}=0.005)$. Die Widerstandsfähigkeit des Baumwachstums gegenüber extremer Trockenheit war allgemein hoch und variierte nicht bei den Arten und Landnutzungen. In dieser Studie variierte die Reaktion individueller Baumarten bei den verschiedenen Landnutzungen, was die Schwierigkeiten bei der Vorhersage der Reaktionen der urbanen Wälder auf projektierte Zunahmen bei dem Auftreten extremer Klimaereignisse verdeutlicht. Die Reaktionen des Baumwachstums auf Trockenheit variierte auch innerhalb der relativ kleinen Spannbreite von Wachstumsbedingungen in dieser Studie. Untersuchungen an einer größeren Auswahl an Standorten, die das volle urbane Forstkontinuum umfassen, würden wahrscheinlich eine noch größere Variation an Reaktionen von Bäumen auf extreme Klimaänderungen demonstrieren.

Resumen. La comprensión de la respuesta de los bosques urbanos a los eventos climáticos extremos, como las sequías, será esencial para predecir los impactos del cambio climático en la cobertura arbórea y los servicios de los ecosistemas relacionados. Este estudio evaluó la variación en el crecimiento de los árboles, la resistencia a la sequía (crecimiento durante la sequía) y la resiliencia (crecimiento en el período siguiente a la sequía) a través de cuatro categorías de uso del suelo (construcción, vialidad, parque y bosque semi - natural) y cuatro especies (Acer saccharum, Gymnocladus dioicus, Liriodendron tulipifera y Pinus strobus) en el Morton Arboretum en los suburbios de Chicago, Illinois. El crecimiento y la resistencia a la sequía varió como una interacción entre el uso del suelo y especies $(\mathrm{F} 15,100=5.25, \mathrm{p}<0.001 ; \mathrm{F} 15,100=2.42$, $\mathrm{p}=0.005005)$. La resiliencia del crecimiento de los árboles a la sequía extrema fue generalmente alta y no varió entre las especies y los usos del suelo. En este estudio, las respuestas de las especies individuales de árboles a la sequía variaron según los usos del suelo, lo que demuestra la dificultad de predecir la reacción de los bosques urbanos a los aumentos proyectados en la frecuencia de eventos climáticos extremos. La respuesta de crecimiento de los árboles a la sequía varió incluso en todo el rango relativamente estrecho de condiciones de crecimiento aquí estudiado. La investigación de una amplia gama de sitios, que abarca la gama completa del continuum bosque urbano, probablemente demostraría una variación aún mayor en la respuesta del árbol a los eventos climáticos extremos. 